\title{
Integrating archival analysis, observational data, and climate projections to assess extreme event impacts in Alaska
}

\author{
Nathan P. Kettle ${ }^{1,2}$ D J John E. Walsh ${ }^{1,2} \cdot$ Lindsey Heaney ${ }^{1,2} \cdot$ Richard L. Thoman Jr ${ }^{1,2}$. \\ Kyle Redilla ${ }^{1} \cdot$ Lynneva Carroll $^{3}$
}

Received: 13 April 2020 / Accepted: 19 October 2020 / Published online: 5 November 2020

(C) The Author(s) 2020

\begin{abstract}
Understanding potential risks, vulnerabilities, and impacts to weather extremes and climate change are key information needs for coastal planners and managers in support of climate adaptation. Assessing historical trends and potential socioeconomic impacts is especially difficult in the Arctic given limitations on availability of weather observations and historical impacts. This study utilizes a novel interdisciplinary approach that integrates archival analysis, observational data, and climate model downscaling to synthesize information on historical and projected impacts of extreme weather events in Nome, Alaska. Over 300 impacts (1990-2018) are identified based on analyses of the Nome Nugget newspaper articles and Storm Data entries. Historical impacts centered on transportation, community activities, and utilities. Analysis of observed and ERA5 reanalysis data indicates that impacts are frequently associated with high wind, extreme low temperatures, heavy snowfall events, and winter days above freezing. Downscaled output (2020-2100) from two climate models suggests that there will be changes in the frequency and timing of these extreme weather events. For example, extreme cold temperature is projected to decrease through the 2040s and then rarely occurs afterwards, and extreme wind events show little change before the 2070s. Significantly, our findings also reveal that not all weather-related extremes will change monotonically throughout the twenty-first century, such as extreme snowfall events that will increase through the 2030s before declining in the 2040s. The dynamical nature of projected changes in extreme events has implications for climate adaptation planning.
\end{abstract}

Keywords Archival analysis · Alaska Climate $\cdot$ Extreme events $\cdot$ Socio-economic impacts . Weather

Nathan P. Kettle

nkettle@alaska.edu

Extended author information available on the last page of the article 


\section{Introduction}

Extreme weather events and climate change pose significant risks to society, including impacts to transportation and infrastructure, public health, economies, and food and water security (Bouwer 2019). Losses from extreme weather events have grown dramatically over the past several decades from shifting exposures and vulnerabilities as well as increases in the frequency of some events, although impacts vary spatially and interannually. Some types of extreme events are likely to increase in the future (IPCC SREX 2012; USGCRP 2018).

Planners seeking to support climate adaptation are increasingly interested in understanding how risks and impacts may change (Lempert et al. 2018). Addressing this need requires understanding historical climatologies and impacts as well as projections of how extreme events may change. However, risk assessments are complicated by challenges in monitoring and assessing long-term historical trends in impacts and estimating projected change (Downton et al. 2005; Morss et al. 2011). This is especially the case in Alaska, where sparse observational networks limit documentation and analyses of extreme weather events and impacts are often only documented for individual events (Brunner et al. 2004; Thoman et al. 2020). As such, there is a limited understanding of historical trends and projected impacts from extreme weather events in the Arctic, though impacts and local observations of change are documented (AMAP 2017; Larsen et al. 2014; Markon et al. 2018).

Innovative interdisciplinary methods are needed to assess projected socio-economic impacts of extreme weather events in the Arctic. Top-down bottom-up impact assessments, which bring together western science and local knowledge of places, priorities, and thresholds, offer significant potential to identify future impacts of local concern and increase opportunities for improving the usability of scientific information in decision-making (Mastrandrea et al. 2010). Top-down approaches are often based on global or regional climate projections and assess potential impacts quantitatively; these assessments are often generalized compared with the complexities of local contexts. Bottom-up approaches assess impacts based on local understandings of risks and the factors that influence vulnerabilities.

The objective of this paper is to project socio-economic impacts associated with climate change and extreme weather events based on historical impacts. Our novel approach for assessing future potential risks brings together archival analysis, historical climatology, and regional climate downscaling. Our assessment begins by identifying historical socio-economic impacts of extreme weather events over nearly three decades based on an analysis of newspaper coverage and a national-level database of storm impacts. Climate model downscaling is then performed for four types of extreme events that were linked most frequently to socio-economic impacts: extreme cold temperatures, winter days above freezing, high-speed wind events, and heavy snowfall events. Potential impacts associated with changes in extreme weather events are then discussed. The assessment is based in Nome, Alaska, which experiences a variety of weather-related impacts, has a relatively long and complete record of weather data compared with other regions in Alaska, and has a newspaper that documents significant local events. We conclude by discussing implications for planning in Nome and more broadly across Alaska.

\section{Literature review}

Multiple terms describe weather-related events that adversely affect societal outcomes, including extreme weather, hazardous weather, and high-impact weather. These events include 
tornadoes, hurricanes, coastal and winter storms, floods, storm surge, and drought. Definitions of extreme weather events vary across disciplinary perspectives (Morss et al. 2011). For example, climatologists and social scientists often define extreme events based on threshold exceedance values (tails in the climatological distribution) or notable societal impacts, respectively (Changnon 2009; IPCC SREX 2012). There is often overlap across approaches, as societal impacts can guide the selection of climatological thresholds of extreme events. This study uses the term weather-related extremes to describe extreme events where information is climatologically and societally integrated.

\subsection{Climate change and extreme weather}

Some weather- and climate-related extremes have changed since the 1950s, including fewer cold days and nights globally and shifts in heavy precipitation events that vary regionally (IPCC SREX 2012). Projected changes in these extreme events are often described as monotonic trends (IPCC SREX 2012; USGCRP 2018). In the Arctic, there is strong evidence that temperatures have increased in terms of climatological means, yearly averages, and daily highs (AMAP 2017). Higher temperatures have contributed to sea ice loss, more frequent severe wildfires, and a shortened snow season in Alaska (Thoman et al. 2020; Thoman and Walsh 2019). There is high confidence in future changes for air temperature, precipitation, and sea ice in the Arctic. For some variables such as temperature, precipitation, and wind, changes in extreme values are projected to be larger than changes in the mean (IPCC SREX 2012).

Lack of high-quality long-term data creates challenges in quantifying changes in climate extremes, especially in the Arctic where observational networks are sparse. Airport observations provide site-specific data in some rural communities; however, these data may contain missing values for extreme events. For example, data from some high-speed wind events are often missing because of instrument riming or other malfunction (Redilla et al. 2019). Atmospheric reanalyses, which reconstruct the atmosphere state based on assimilating observational data into a weather prediction model that is continually constrained to be consistent with available observations, are especially well suited for estimating system states where observations are limited or have missing data. These data generally represent conditions averaged over a grid cell, rather than a precise location. The reanalysis used in this study has grid cells that are approximately $30 \mathrm{~km}$ on a side (see Section 4.3).

Projections of climate change, including extreme events, are desired in Alaska to provide insight into planning efforts (Knapp and Trainor 2015). Global climate models (GCMs) provide projections of the expected large-scale response to anthropogenic climate change. However, regional changes are not well resolved within GCMs, which limits their utility for anticipating impacts on local communities and resources. Dynamical downscaling, which uses a regional climate model forced at the boundaries by a GCM, provide physically consistent projections of many variables to explore future climate variability for local applications.

\subsection{Socio-economic impacts}

Several local- to national-level studies have investigated socio-economic impacts of historical weather-related extreme events (see Bouwer 2019). This includes research on the impacts to specific sectors, such as agriculture, public health, and transportation (Lesk et al. 2016; Mitsakis et al. 2014), and impacts from specific hazards such as drought, lightning, ice and winter storms, and floods (Ashley and Ashley 2008; Call 
2010; Dow 2010; Downton et al. 2005). Although findings vary based on the hazard type, geographic region, spatial and temporal scope, and data sources used, multiple themes emerge from this research. First, deaths, injuries, and economic losses are among the most frequently reported impacts. Downstream impacts, including food security, social controversies, economic disruption, and public health, are reported less often (Bouwer 2019; Morss et al. 2011). Second, economic impacts from extreme weather events have increased, though these trends are not always directly linked to increases in event frequency, highlighting the importance of social changes, vulnerability, and adaptation in shaping risks (Bouwer 2011). Third, the level of impact stems from a complex set of cross-scale interactions within coupled socio-ecological systems that lead to differential vulnerabilities. Vulnerability is influenced by the interaction of sensitivity, exposure, and adaptive capacity (Turner II et al. 2003). As such, extreme impacts may result from the combination of several non-extreme events (Leonard et al. 2014). Fourth, research on the historical socio-economic impacts of extreme weather events in Alaska often focuses on individual events (AMAP 2017; Brunner et al. 2004). For example, the 2018 record low Bering sea ice extent led to shifting marine mammal die off events and sightings of animals outside their traditional range, loss or impairment of maritime subsistence activities, loss of an ice airstrip, and enhanced coastal flooding (Thoman et al. 2020). Marine ecosystem impacts of recent extreme years in the Pacific subarctic region have also been documented (Huntington et al. 2020). Other research investigated weather impacts to water and sanitation systems (Penn et al. 2016).

Some studies have reported on projected losses from extreme weather events. The majority of these studies focus on risk assessments at the national or international level (Bouwer 2013; Handmer et al. 2012). These assessments often quantify direct economic damages and losses, which provide some insight into the severity of extreme weather events. Other projected indirect losses and impacts, such as injuries, business interruptions, psychological trauma, and community livelihoods, are less often estimated. Key uncertainties in projecting losses from extreme events include societal changes, greenhouse gas emission scenarios, and assumptions regarding the linear relationship between hazard frequency and impacts.

Multiple methods are used to assess socio-economic impacts from extreme weatherrelated events, including interviews, archival analysis, and national-level databases. National-level databases can provide standardized metrics for assessing and comparing the spatial and temporal distribution of historical impacts and as a basis for projecting impacts (e.g., Yuan and Sun 2019). However, these databases often have several limitations, such as a greater focus on economic impacts and more attention to immediate impacts (Ashley and Ashley 2008; Gall 2015). The compounding nature of impacts also makes it difficult to quantify impacts (Leonard et al. 2014). Archival analysis, such as newspaper coverage, is also well suited for capturing locally relevant impacts from extreme weather events, though there may be issues of selection or description bias (Dow 2010; Earl et al. 2004; Ungar 1999). In Alaska, archival analysis may be especially well suited for assessing historical socio-economic impacts, identifying locally defined thresholds and providing a basis for projecting impacts under various climate scenarios where long-term local news coverage exists (Duerden 2004). No studies were identified that used archival analysis, observational climate data, and regional downscaled climate models as a basis for anticipating socio-economic impacts of extreme weather events. 


\section{Nome, Alaska}

The City of Nome provides an ideal location for the examination of historical and projected weather-related impacts, given their previous experience with weather-related hazards, rapid rate of climate and environmental change, high quality long-term weather station measurements, and availability of local newspaper coverage. Nome (population 3600) is located on the southern coast of the Seward Peninsula in northwest Alaska (Fig. 1). The city is a regional and economic hub for 16 villages. Stakeholders in Nome include the municipality, maritime and mining operators, and subsistence hunters. Alaska Natives are the largest ethnic population group, representing over half the population (ADLWD 2018). Wild food resources are an important nutritional source, which account for 370 pounds per person annually in northwest Alaska (Fall 2016). Expanding and upgrading the Port of Nome to attract revenue, develop natural resources, and support national security interests is a priority for some residents, though increases in shipping pose risks to subsistence. Although Nome does not experience billiondollar disasters, the impacts of weather-related extremes are arguably greater on a per capita basis compared with more urban locations in the contiguous USA, as Nome may only be accessed via air or water, have limited back-up options when critical infrastructure is damaged and people are engaged in mixed cash-subsistence economies.

Hourly weather measurements at the Nome airport, which is located approximately $3 \mathrm{~km}$ northwest of downtown Nome, have been made since 1946. The record of hourly observations is more than 99\% complete for the period of this study (1990-2019). Weather observations were changed to the Automated Surface Observation System in 1998, a change that did not show significant discontinuities in the temperature and wind reports during the mid-1990s through 2019 (Redilla et al. 2019).

Nome's average temperatures increased by $3.4^{\circ} \mathrm{C}$ in winter and $1.6^{\circ} \mathrm{C}$ in summer over the past 60-70 years (ACRC 2020; AMAP 2017). Some research has investigated extreme weather events in Nome, including storm surge intervals and the oceanographic and climatological driving forces behind high-impact storm events in Nome (Mason et al. 1996; Mesquita et al. 2009). Sea ice regimes across north and northwestern Alaska have shifted over the past three decades, including delayed freeze-ups and earlier break-up events (Rolph et al. 2018). Increases in open water days are linked to increased rates of coastal erosion (Overeem et al. 2011). Other research suggests that the frequency of high-speed wind events in northwest Alaska is increasing, including winds that are too fast for safe hunting in boats (Redilla et al. 2019). Impacts to transportation systems, access to wild foods and subsistence opportunities from roads and trails, and increased vessel traffic are key weather-related concerns among Nome residents (Kettle et al. 2017; Parks et al. 2019). In response to these changing conditions, several local- to national-level planning efforts are occurring in Nome (Birchall and Bonnett 2020; Kettle et al. 2017; USACE 2019).

\section{Data and methods}

Our top-down bottom-up assessment of historical and projected socio-economic impacts from weather-related extremes was based on the analysis of multiple datasets. Archival analyses of the Nome Nugget newspaper and Storm Data were used to assess historical impacts. Weekly Nome Nugget publications provided insight into salient local and regional issues. NOAA's Storm Data provided a database of weather-related extreme events and impacts that supplemented the 


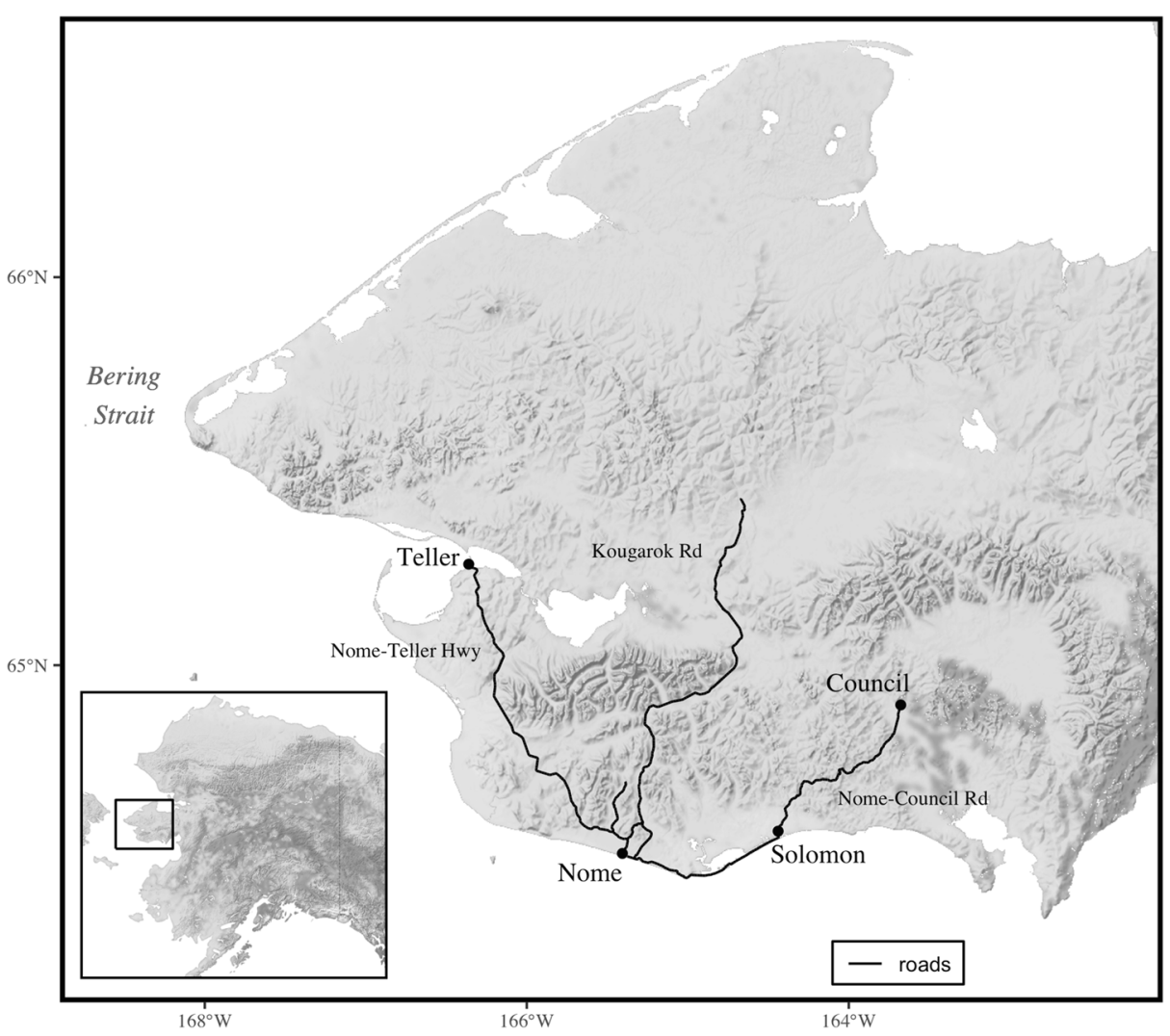

Fig. 1 Nome, Alaska. Highways outside of Nome are not generally maintained during the winter (OctoberMay), though these dates are weather-dependent

newspaper assessment and mitigated against selection and description bias (Earl et al. 2004; NOAA 2019). The historical climatology was assessed based on observational and reanalysis data. Projected changes in weather extremes are based on the outputs from two dynamically downscaled GCMs. Findings from the archival analysis, historical climatology, and downscaled climate projections were used to project impacts. These data and methods are detailed below.

\subsection{Nome Nugget}

A preliminary list of potentially relevant articles was identified based on a manual review of article titles using keywords related to weather (weather, climate, sea ice, wind, snow, hot, cold, freezing/frozen, rain, permafrost, storms, breakup), hazards (coastal, erosion, oil spills, mining, search and rescue, relocate, food security, damage, pollution, flood, dry, drought, health, fire), infrastructure (roads, utilities, power, electricity, water, sewer, village, port), subsistence (reindeer, musk-ox, fish, berries, seal, hunter, environment, regulations, fish camp, birds, walrus, mammals, hunter), and transportation (shipping, roads). This list was developed based on a review of extreme event impacts identified in local planning documents, including the comprehensive plan, hazard mitigation plan, and tribal climate adaptation plan (City of Nome 2012, 2017; Kettle et al. 2017). The full population of newspaper articles was accessed 
from microfiche at the University of Alaska Fairbanks library (1990-2009) and online archives from the Nome Nugget website (2010-2018). Newspaper articles were coded manually for themes related to the extreme event type, socio-economic impacts, and year and month of coverage. Sea storms consisted of both autumn and coastal storms, and snowstorms consisted of events with both wind and snow. Extreme event types were coded based on the journalist's description, rather than the historical climatology. Weather events and impacts occurring fewer than five times were labeled as "other." News coverage of impacts occurring at least 2 weeks after the extreme event occurred were coded as "other," rather than the publication month. In total, 225 articles were identified that discussed weather-related impacts.

\subsection{Storm data}

Socio-economic impacts in Storm Data were identified based on a review of paper publications (1990-1995) and the online database (1996-2018), as the online database only included convective events prior to 1996 (NOAA 2019). This review identified 114 Storm Data entries, 34 of which discussed socio-economic impacts. Impacts from identical event narratives were counted once when individual storm events were entered multiple times under different hazard event types. This resulted in 26 unique narratives describing impacts. Event types were classified based on Storm Data categories, except for the following merged categories: wind (strong wind and high wind), snowstorm (blizzard and winter storm), and flood (coastal flood and flood). Events and impacts occurring fewer than five times were classified as "other."

\subsection{Climatology and projections}

The assessment of historical climatology (1990-2019) and decadal projections of change (2020-2100) focused on four types of extreme weather events associated most frequently with impacts identified in the archival analysis in Nome: extreme cold temperatures, winter days above freezing, heavy snow, and high winds (Fig. 2). Two sources of data were analyzed to provide a complementary assessment of the historical climatology: quality-controlled hourly weather observations from the Nome airport and 30-km spatial resolution hourly ERA5 (European Center for Medium-Range Weather Forecasting Reanalysis for the Atmosphere, version 5) reanalysis data (C3S 2017; ISU 2020).

For decades through 2100, projections of hourly air temperature, snowfall, and winds were obtained from a dynamical downscaling of NOAA's Geophysical Fluid Dynamics Laboratory (GFDL) Climate Model, version 3 (CM3) and Community Climate System Model, version 4 (CCSM4) as described by Bieniek et al. (2018) and Lader et al. (2018). Selecting models at the opposite ends of the sensitivity spectrum (CM3 high end, CCSM4 low end) captured a range of uncertainty associated with model selection and minimized the computational resources required for downscaling. Previous evaluations suggest that these models capture the spatial distributions of temperature and precipitation and are among the models that most accurately reproduce the historical climate of Alaska (Lader et al. 2017; Walsh et al. 2018). The greenhouse gas forcings of these model simulations followed the Representative Concentration Pathway (RCP) 8.5 scenario, which are the scenario most closely tracked by recent emissions.

The reanalysis and GCM projection data were dynamically downscaled using the Advanced Research core of the Weather Research and Forecasting (WRF) model over the Alaska domain (Bieniek et al. 2016; Skamarock et al. 2008). The model provided 20-km spatial resolution data that better accounts for the complex Alaska topography than the relatively 


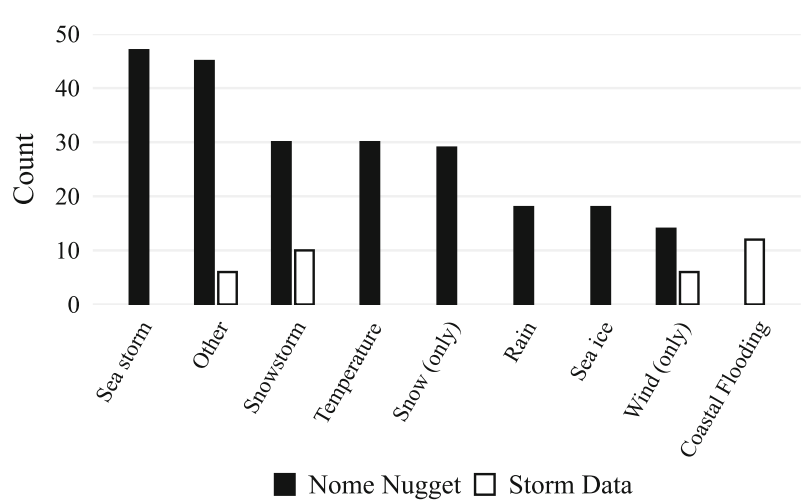

Fig. 2 Weather-related extreme events linked to socio-economic impacts in Nome, Alaska (1990-2018). The wind category only included extreme events where wind was the sole hazard

coarse (100-200 km) reanalysis or GCM data (Bieniek et al. 2016). The output was saved at hourly time increments to enable temporal resolution of extreme events. The WRF model was reinitialized at 48-h intervals with an additional 6-h spin-up time and a spectral nudging procedure that constrained the downscaled fields to be consistent with the driving reanalysis or GCM. The downscaling parameterizations were selected to optimize performance over Alaska (Zhang et al. 2016). Clouds and precipitation in the WRF model were parameterized by the Morrison 2-moment and Grell 3D cumulus schemes (Morrison et al. 2009). Shortwave and longwave radiative effects were parameterized by the Rapid Radiative Transfer Model for GCMs (Iacono et al. 2008). Boundary and surface layer processes utilized the Mellor-YamadaJanjić (Janjić 1994) and Janjić Eta (Monin-Obukhov) schemes, respectively. A thermodynamic sea ice model was coupled with the NOAA land-surface model within WRF to better account for the thermal conditions over sea ice (Zhang and Zhang 2001). A quantile mapping procedure addressed systematic errors by adjusting the model's historical distribution of each variable to match the corresponding historical distribution from ERA5 and then reapplying the adjustment factors to each quantile of the future distributions (Redilla et al. 2019). The quantile mapping used the ERA grid cell with its center closest to Nome.

Relative to ERA-Interim, downscaling improves the spatial representation of temperature and precipitation in Alaska's complex terrain (Bieniek et al. 2016). Additionally, the spatial distributions of temperature and precipitation were consistent with the few available gridded observational datasets that account for topography. The downscaled precipitation generally exceeded observationally derived estimates in all seasons over mainland Alaska, while it was lower than observations in the southeast.

Thresholds were defined based on locally specified values when possible. Extreme cold temperatures were set as days when the minimum temperature was less than or equal to $34.3{ }^{\circ} \mathrm{C}\left(-30^{\circ} \mathrm{F}\right)$ - a value discussed widely in a Nome Nugget article entitled "Nome in long deep freeze" where multiple impacts to activities, utilities, and transportation were referenced (Haecker 2012). The criterion for an above-freezing day during January-February was the daily maximum temperature $0{ }^{\circ} \mathrm{C}\left(32^{\circ} \mathrm{F}\right)$ or higher. The snow depth threshold was set at $20.3 \mathrm{~cm}(8 \mathrm{in}$.) of snowfall - a slightly lower value than specified in Nome's Hazard Mitigation Plan (12 in.) in order to capture major snowfall events that also contribute to overall snow accumulation (City of Nome 2017). High-speed wind events were defined as occurrences of winds $48.3 \mathrm{~km} / \mathrm{h}$ (30 mph) or greater for at least 10 consecutive hours. This combination of speed and duration results in a set of storm 
events for which the average return interval is approximately 1 year (Redilla et al. 2019). We note that station reports of variables such as temperature, snowfall/snow depth, and wind speed are made in English units ( ${ }^{\circ} \mathrm{F}$, inches, miles per hour) in the USA. Accordingly, these units typically appear in media coverage (e.g., Nome Nugget) of weather and climate events. While the corresponding thresholds used here are integer values in English units, the equivalents in metric (SI) units $(\mathrm{cm}$, $\mathrm{km} / \mathrm{h}$ ) have non-integer values. For completeness, we generally provide the values in both units.

\section{Socio-economic impacts in Nome}

Over 300 socio-economic impacts $(n=322$ Nome Nugget; $n=44$ Storm Data $)$ from extreme weather-related events were identified in Nome between 1990 and 2018, including impacts to transportation, activities, utilities, and building structures (Fig. 3). Impacts occurred year-round, with the most in January and August and the fewest in July (Fig. 4). Impacts were most often related to wind, sea storms, snowstorms, snow, and temperature extreme events (Fig. 2).

Annual reported impacts in the Nome Nugget increased between 1990 and 2018 (Fig. 5) - a trend consistent with other research on losses from extreme weather events (Bouwer 2019). Although this increase may be in part related to increased media attention that led to more reporting as well as societal changes that contributed to increased vulnerability, these changes may also be related in part to the historical climatology. For example, both the annually reported impacts from wind-related events (wind, sea storms, and winter storms) and the number of high-speed wind events increased between 1990 and 2018. The high number of impacts reported in 2004, 2005, and 2011 were associated with major coastal storms and disasters (State of Alaska 2018).

There were some differences in the types and number of impacts reported across the datasets. Few impacts to subsistence activities, mining, and aviation were reported in Storm Data. Impacts in Storm Data were most frequently reported during the autumn, while impacts in the Nome Nugget were reported most often in January and August (Fig. 4). The limited number of reported impacts in

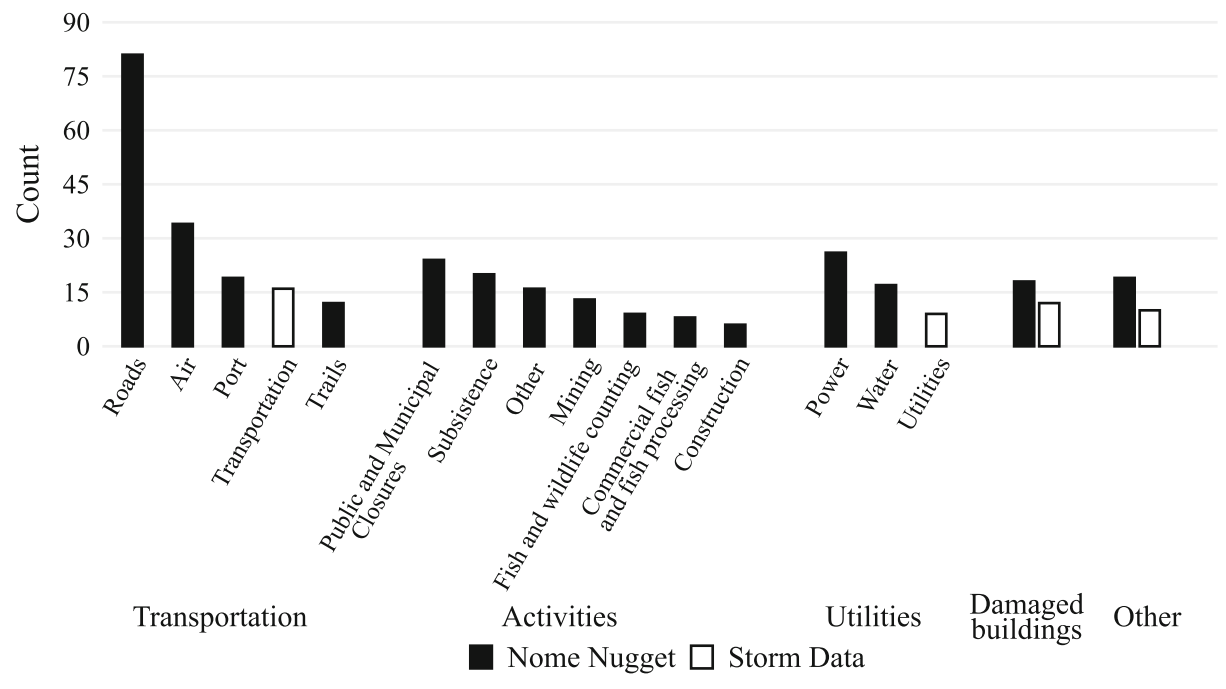

Fig. 3 Socio-economic impacts from weather-related extremes in Nome, Alaska (1990-2018). Major categories of impacts compiled from the Nome Nugget and Storm Data included transportation, activities, utilities, and damaged buildings. Other impacts included those that were identified fewer than five times 
50

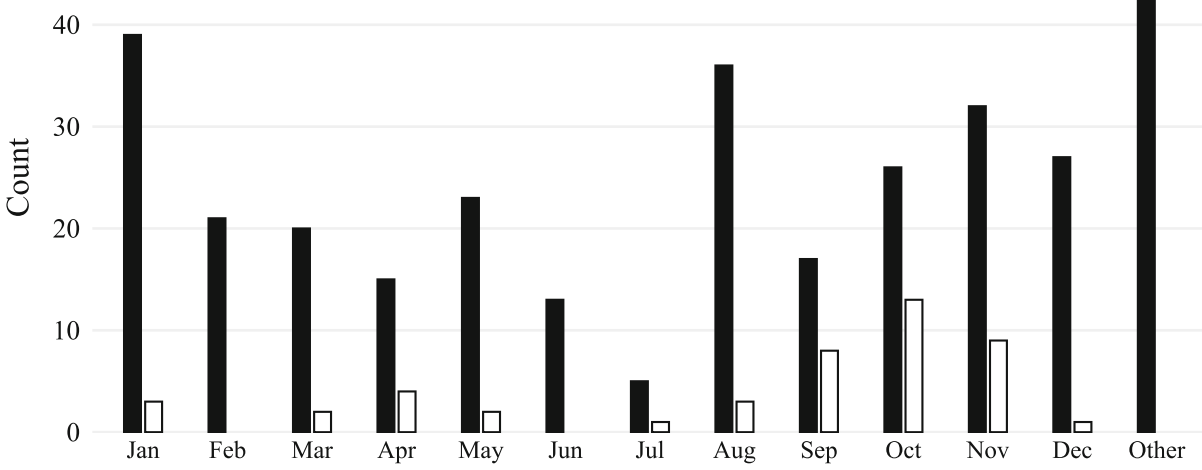

$\square$ Nome Nugget $\square$ Storm Data

Fig. 4 Monthly distribution of socio-economic impacts in Nome, Alaska, from weather-related extremes (19902018). News coverage of impacts occurring at least two weeks after the extreme event occurred were coded as "other," rather than the publication month

Storm Data for Nome prior to 1996 (four entries and three impacts from 1990 to 1995) was likely related to the modernization of the National Weather Service in the mid-1990s, which assigned Storm Data entries to the then newly established Warning Coordination Meteorologist position or their designee (Friday 1994; NWS 2018). Socio-economic impacts reported in the Nome Nugget and Storm Data are detailed below. Unless otherwise specified, $n$-values refer to the Nome Nugget.

\subsection{Transportation}

Impacts to roads, aviation, the port, and off-road trail systems were among the most frequently reported impacts. Impacts to roads centered on infrastructure $(n=30)$, clearing snow $(n=30)$, and hazardous driving and walking conditions on icy or flooded roads $(n=20)$. Impacts to road

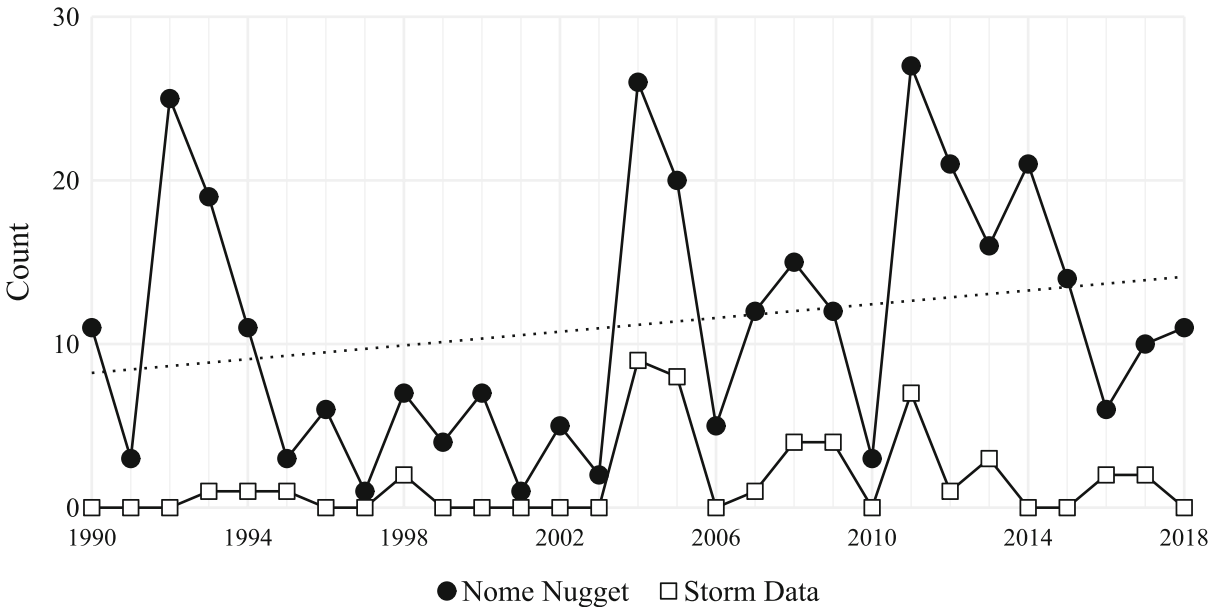

Fig. 5 Trend in socio-economic impacts from weather-related extremes in Nome, Alaska (1990-2018). Dashed line is linear trend for reported impacts in the Nome Nugget 
infrastructure occurred primarily from sea storms that led to potholes and washouts and from warm spring temperatures following above-average snowpack years that created overflow. Winter thaw events also led to icy roads and unsafe travel. Although each of the three gravel highways leaving Nome experienced weather-related impacts, the Nome-Council Road was especially vulnerable to washouts, erosion, and closures (Mason et al. 1996). For example, road closures from coastal storms in October 2004 and November 2011 contributed to 10 occupied residences in the Council area being isolated from Nome and \$24 M in road damages, respectively. Snow removal was a major expense (overtime wages and fuel and equipment costs) to ensure safe travel within Nome and provide access to surrounding villages in the spring, especially during heavy snow years, back-toback storms, or when the wind blew snow back onto roads after removal. In describing the effect of wind on snow depth and the need to rebuild sections of the gravel highway system in a manner that accounts for local wind a transportation specialist stated:

Nome and the area isn't like most areas in the state. If it snows a foot, there is usually only a foot of snow in the road cut, but up there the snow comes in horizontally and cuts are completely filled causing big problems come clearing time (Leeper 1999).

Limited highway access to surrounding areas in the spring due to impassable roads from snowfall also posed an economic threat to mining and tourism.

Air transportation was often impeded by limited visibility, which led to canceled and delayed flights lasting from a few hours to days. Cargo flight delays led to shortages of goods at grocery stores, mail delays, and business losses (e.g., suspended salmon purchasing operations). Canceled passenger flights contributed to individuals missing personal and business appointments as well as medical appointments for procedures not available in Nome. The closure of the longer runway from frost heaving required that incoming flights use the shorter runway, which has a lighter payload capacity and more stringent visibility requirements.

The Port of Nome experienced multiple infrastructure impacts to the causeway and jetty, docks, and causeway bridge. For example, sea storms in 2004 and 2011 led to $\$ 3 \mathrm{M}$ and $\$ 500 \mathrm{~K}$ in repairs to the Nome Jetty, respectively. Sea ice movement also damaged docks, including broken fendering welds, bowing sheet piling, and ladders. Impacts to port infrastructure, coupled with sea ice blocking the port entrance and sedimentation from sea storms, contributed to multiple impacts. This included reduced draft depth, limited port access, shipping delays, vessel rerouting, reduced delivery frequencies and back-haul voyages (especially if shipments could not be completed before freezeup), and the loss of city revenue from port fees associated with fewer boats using the port (USACE 2019). For example, sea ice delayed the delivery of fuel to Nome in June 2008 and December 2011, the latter of which resulted in legal issues between shipping company and local fuel distributor. Other impacts included damaged barges and vessels, both inside the port and at Cape Nome.

Impacts to trails centered on industrial (mining) and local community activities (limited access to subsistence, travel between villages, and dog racing). For example, unusually warm wintertime temperatures often created overflow and open water on sea ice, lakes, and rivers, which led to dangerous travel conditions. Similarly, limited snow cover during the winter impeded travel for moose hunters and search and rescue operations via snowmobiles. Washouts from coastal storms also limit all-terrain vehicle (ATV) use on trails.

\subsection{Activities}

Multiple activities were affected by extreme weather-related events, including business and municipal closures $(n=23)$, subsistence $(n=21)$, and mining $(n=13)$. Over half $(57 \%)$ of the subsistence 
impacts centered on access and safety, such as impassable roads or trails that limited travel to fish camps and hunting grounds. Unpredictable ice conditions limited days for hunting marine mammals that use ice as a resting platform. Financial costs and safety risks also increased as hunters were forced to travel greater distances. Additionally, there was a temporal mismatch between the availability of wild foods and when regulations permit harvest. Other impacts included restricted caribou harvests from rain on snow events, declining moose population health due to snow and extreme cold spells, harmful algal blooms, and damaged fish camps and meat drying racks.

Weather and sea-ice related impacts to mining were primarily related to operational days $(n=8)$. For offshore winter and summer mining, strong winds and unstable sea ice conditions often limited the number of operation days. For onshore mining, operational days were affected by temperature, snow, and runoff, such as deep snow on roads limited access to mines during the spring. Operational days were further reduced by impacts to equipment and infrastructure, including frozen dredge ponds and water supplies, unsafe travel on unpaved backroads from early thawing, and stranded equipment on sea ice. Some infrastructure impacts adversely affected water quality, such as excavating frozen ditches with heavy equipment that led to the release of sediments and increased turbidity.

Other activity impacts included fish and wildlife monitoring by the State of Alaska $(n=9)$, commercial fishing and fish processing $(n=5)$, construction $(n=5)$, and dog racing $(n=4)$. For example, salmon counting weirs were often damaged or non-operational due to high water, which contributed to underestimating escapement counts. Harsh winters also led to difficulties estimating moose populations, which led to reductions in available hunting permits. A late sea ice breakup contributed to dangerous fishing conditions and less accessible herring, which resulted in local fishers being without one of their primary sources of income within a mixed cash-subsistence economy. Similarly, sea storms reduced the number of fishing days for crabbers, which in one case contributed to a fish processing plant closure. Other impacts include damaged boats and fishing gear as well as building and construction delays from cold temperatures, heavy summer rains, and sea ice.

\subsection{Utilities}

Impacts to the Nome Joint Utility System (NJUS) centered on disconnected power lines, blown fuses in electrical feeders and transformers, dislodged poles, and disruptions in the fuel supply for generators. Power lines often snapped or dislodged $(n=12)$ during high-speed wind events and were especially vulnerable when winds were accompanied by ice accumulation as this led to greater weight on lines. Extended periods of sub-zero temperatures cooled fuel bulk diesel storage tanks, which slowed the delivery of fuel to day tanks. Maintaining and replacing weather-damaged infrastructure was an ongoing expense for the NJUS, such as a 2004 coastal storm that led to $\$ 150,000$ in damages to power lines, poles, and construction materials. Power outages often contributed to temporary business and municipal closures, Internet loss, and frozen residential water pipes. Impacts were often greater when power losses were accompanied by low temperatures, as this often led to frozen water pipes. For example, power loss from a 2008 snowstorm with sub-zero temperatures contributed to 15 reported cases of frozen pipes. Other downstream impacts resulting from the loss of power, such as carbon monoxide poisoning from improper generator use and fires from people trying to thaw pipes were not identified (Call 2010). Few impacts to stormwater and wastewater $(n=8)$ were reported.

Frozen water pipes and clogged sewer vents associated with extended periods of low temperatures were a common challenge in Nome, even in the absence of power loss. As stated by a 
reporter, "It's one of those months when every conversation in Nome starts with 'are your drains working' ... a normal office day at $-30^{\circ} \mathrm{F}$ begins with the chore of firing up that hair dryer to thaw out the toilet" (Haecker 2012). The likelihood of frozen pipes was related to the insulation surrounding the pipes, snow cover, electricity outages, and plugged heater fuel lines.

\subsection{Other impacts}

Other impacts included structural damage to buildings $(n=17)$, impacts to the sea wall and coastal erosion, digging out heater exhaust pipes and vents following heavy snowfall events, low snowfall years causing economic losses for snowmobile companies and difficulties in search and rescue operations, and ruined equipment (e.g., generators) and belongings at subsistence camps. Some weather-related impacts discussed in local planning documents were not identified in the Nome Nugget nor Storm Data, including releveling houses and structures from permafrost thaw and collapsed roofs from heavy snowfall (e.g., City of Nome 2017; Kettle et al. 2017).

\section{Historical climatology and projections in Nome}

Analysis of the observational data and projections centered on extreme cold, winter days above freezing, wind, and snowfall events as these extreme events were often linked to socio-economic impacts (Fig. 2). There were some differences in the event frequency between the observed and ERA5 reanalysis datasets and between the two climate model projection outputs (Fig. 6). The historical frequency of extreme events and projected changes are discussed below.

Extreme low temperature days were projected to decline rapidly by the 2020s and not occur by the 2040s. Even in the most recent decade of the 2010s, most extreme low temperature events occurred prior to 2013. The rapid decline in low temperature days beginning in the 2010 s is likely related to the loss of sea ice cover (Thoman et al. 2020). The frequency of observed extreme low temperature events was similar across both models. Winter days (January and February only) when the maximum temperature exceeds freezing is projected to increase in each of the decades through the 2090s. Because the average January and February temperatures at Nome are well below freezing in the present climate, the daily maximum temperature is presently below freezing on most days in these months. The ongoing and projected climate warming shifts the distribution to the right, increasing the frequency of above-freezing daily maximum temperatures. This shift of the distribution is similar in both models.

Heavy snowfall events were projected to become more frequent through the 2030s and then decline after the 2040s, eventually resulting in fewer events than in the historical period (1980s2010s). The increase in heavy snowfall events in the 2030s was likely related to the projected increase in total precipitation across Alaska and the Arctic (USGCRP 2018). The decrease in heavy snow events in the latter half of the twenty-first century was likely related to the warminginduced change in rain/snow partitioning. The possibility of more frequent heavy rain events at Nome during the cold season raises the possibility of additional hazards related to cold-season flooding and/or icing. The two models were consistent in their projections of short-term (to about 2040) increases followed by longer-term decreases in heavy snow frequencies, although the spread between the two models becomes large by the 2040s when one model (CM3) predicts an earlier onset of the reduced-snowfall regime. The across-model consistency contrasts with the lack of agreement in historical decadal variations depicted by the two observational sources, although 

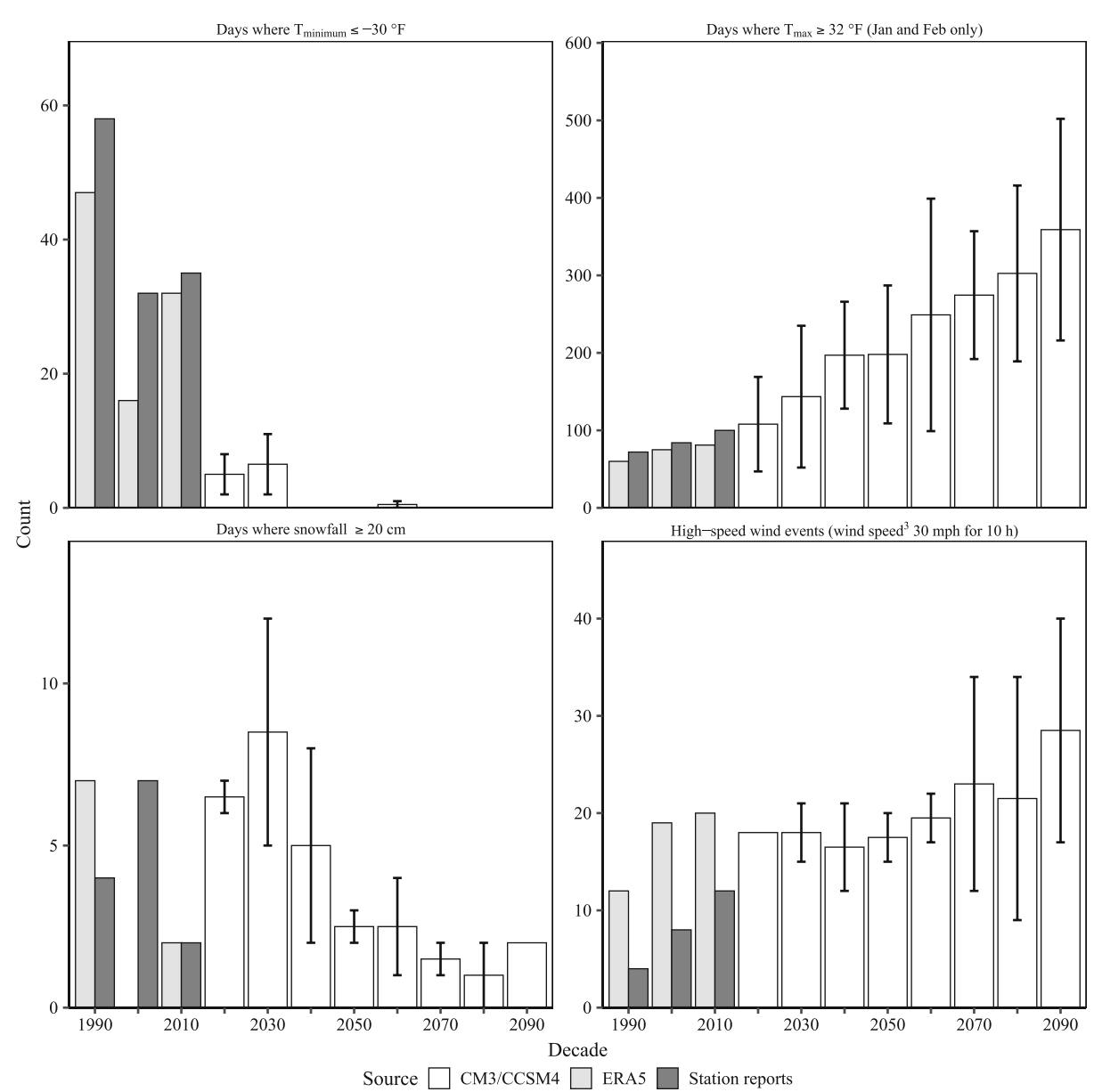

Fig. 6 Historical climatology and projections of extreme events in Nome, Alaska. The count represents the number of days in each decade with extreme cold, winter days above freezing, heavy snowfall, and high-speed wind events. Light gray bars represent ERA5 reanalysis, dark gray bars represent observed data from the Nome airport, and white bars represent averages of downscaled simulations forced by two global climate models (CM3 and CCSM4). Whiskers show the spread between the two models. The CM3 and CCSM4 model projections for decades from 2020 to 2090 compare as follows: (a) In every decade containing any projected cold extremes $\left(-30^{\circ} \mathrm{F}\right.$ or colder), CCSM4 projected the larger number of events; (b) CM3 projected more winter days above freezing in every decade; (c) CM3 projected more heavy snowfall events in the 2030s, 2040s, and 2080s, while CCSM4 projected more events in the other decades (no difference in 2090s); (d) CM3 projected more high-speed wind events for all decades except the 2040s (no difference in the 2020s)

both sources agreed on historical average frequencies of about four events per decade. Differences in historical decadal variability was likely related to the influence of wind and blowing snow that often results in gauge undercatch (McAfee et al. 2013).

The frequency of high-speed wind events per decade at Nome nearly doubled from the 1990 s to 2010 s according to both the station data and the ERA5 reanalysis. Differences between the observed record and ERA5 were likely related to the underreporting of high-speed wind events at the Nome airport due to anemometers shutting down at higher wind speeds and heavy wet snow impeding the movement of the cup anemometer 
(Redilla et al. 2019). High-speed wind events are not projected to change notably through the 2060s relative to the historical climatology from the ERA5 reanalysis. Beginning in the 2070s, there is less certainty regarding how the number of projected high-speed wind events will change. Although the projection showed an increase of high-speed wind events from 2070 to 2100 , the increase was essentially a small residual resulting from the differences in the CM3 and CCSM4 climate model outputs (in all decades except 2040, the CCSM4 model projected more extreme wind events). This result was consistent with the lack of agreement among GCMs on the future changes in storm characteristics (AMAP 2017; Walsh et al. 2020).

\section{Projected weather-related extreme impacts}

Projections of extreme cold temperatures, winter days above freezing, high wind, and heavy snowfall - the events linked to historical impacts reported in the Nome Nugget and Storm Datahave implications for potential future impacts in Nome. Below we describe projected impacts based on shifts in the climatology of these extreme events, which provides insight into how potential impacts may change (Bouwer 2019; Morss et al. 2011). We also discuss how these impacts may be influenced by other long-term changes in climate, given the compounding and interacting nature of extreme weather-related hazards (Leonard et al. 2014). We then discuss the implications of these projected changes in extreme events for planning in Nome. Shifts in socio-economic conditions and adaptation are not incorporated into the discussion of potential impacts.

The city's cost for snow removal on roads from heavy snowfall events may increase through the 2030s before declining in the 2040s to 2090s. Coastal roads that provide access to seasonal subsistence villages and camps, such as the Nome-Council Road, may be vulnerable to increased erosion in the near term due to increased wave action from high-speed wind events beginning in the 2070s. However, there is lack of agreement among our downscaled models regarding future changes in storm characteristics. Coastal erosion may be further exacerbated from sea ice loss in the Bering Sea and a longer open water season (Thoman et al. 2020).

There may be fewer water utility freeze-ups at residential homes as a result of fewer (rare) projected days below $-30{ }^{\circ} \mathrm{F}$ in the 2020 s, relative to $1990-2010$. At the same time, water pipes may be more susceptible to freezing with less snowfall accumulation for insulation. Impacts to power and electricity from high-speed wind events are not likely to change till the end of the twenty-first century, as the climate models provide no basis for anticipating changes in the frequency of high-speed wind events through the 2060s. Dangerous travel conditions during January and February are also likely to increase in association with melted snow and overflow conditions, which are linked to temperatures above freezing.

The types of historical weather events linked to impacts may also shift in Nome. For example, impacts from freezing rain and rain-on-snow events, which were not reported often in the Nome Nugget, nor analyzed in this study, may become more frequent with increasing winter temperatures (Bieniek et al. 2018). Such events could lead to increases in unsafe driving conditions, canceled or delayed flights, food shortages for caribou, broken electrical lines, and limited access to subsistence foods. Additionally, future sea ice loss, which was not modeled in this study, is likely to shape future risks. For example, impacts to the physical infrastructure of the Port of Nome may increase over the next few decades as the proportion of sea storms over open water increases due to sea ice loss (Wang et al. 2012). Additionally, impacts from sea storms to buildings and mining activities may increase over the next few decades, given loss of 
sea ice in Norton Sound (Fang et al. 2018; Thoman et al. 2020). Impacts to road transportation associated with potential increases in the rate of snowmelt during spring break-up were not assessed because of the difficulty in determining thresholds. Break-up characteristics (duration, timing) represent areas of additional research needed to assess future impacts.

The projected changes in extreme weather-related events have implications for climate adaptation planning in Nome. For winter days above freezing, additional funds may be needed for the treatment and maintenance of icy roads. Similarly, additional budgeting for snow removal may be required through the 2030s before declining in the 2040s as heavy wintertime precipitation events shift from snow to rain (Bieniek et al. 2018). The non-monotonic shifts in extreme snowfall events in Nome suggest that planning choices that focus on easily changed (or reversed) actions may be appropriate when communities must live with potential pathdependent consequences of decisions (Hallegatte 2009). Planning choices that focus on costbenefit analysis should account for how the economic utility of strategies may be affected by the timing of non-monotonic shifts in the frequency of extreme events. Changes in wind are not likely to have a significant impact on planning in Nome as potential changes are not likely to occur until 2060, which is beyond typical planning windows, and there is uncertainty regarding the direction and magnitude of change.

\section{Conclusion}

This study revealed multiple weather-related impacts from extreme events to transportation, utilities, activities, and subsistence in Nome, Alaska. Interpretation of downscaled climate model outputs from high-speed wind events, heavy snowfalls, extreme cold temperature, and winter temperature days above freezing - four extreme weather events linked to socio-economic impacts in the historical climatology - suggests that there will be some changes in the frequency of extreme weather-related events in the decades to come. Extreme cold events are expected to continue a decreasing trend, high-speed wind events show no notable changes over the next few decades, winter days above freezing are expected to increase, and heavy snowfalls may increase through the 2030s before declining in the 2040s. In all likelihood, the seasonality, duration, and other characteristics of these events will also change. In other words, not all weather-related extremes will change monotonically throughout the twenty-first century (IPCC SREX 2012; USGCRP 2018). These findings suggest that other communities' planning for climate impacts could expect differences in the direction and frequency of future extreme events and impacts.

The top-down bottom-up approach used in this study enabled the integration of archival analysis, local understanding of priorities and thresholds, observational data, and downscaled climate projections to assess historical and projected socio-economic impacts from extreme weather-related events (Mastrandrea et al. 2010). This integrated assessment approach offers significant potential for focusing downscaled climate projections on extreme weather-related events that are grounded in community priorities. Extension of this methodology to other regions is dependent on the availability of local information to guide climate projections of the extreme events that are aligned with local impacts of concern and the identification of thresholds. In Alaska, some newspaper coverage may be available in other regional hub communities in northwest and northern Alaska for the past 30 years to provide insight into local context (e.g., Arctic Sounder). In regions where newspaper coverage is not available, alternative methods for obtaining information on local priorities, concerns, and thresholds could include combinations of interviews and reviews of local planning documents. 
Acknowledgements This research was financially supported by the Alaska Center for Climate Assessment and Policy (ACCAP), a Regional Integrated Sciences and Assessments program of the National Oceanic and Atmospheric Administration (Award NA16OAR4310162) and the United States Department of Agriculture, National Institute of Food and Agriculture, Hatch Project (1018914).

Open Access This article is licensed under a Creative Commons Attribution 4.0 International License, which permits use, sharing, adaptation, distribution and reproduction in any medium or format, as long as you give appropriate credit to the original author(s) and the source, provide a link to the Creative Commons licence, and indicate if changes were made. The images or other third party material in this article are included in the article's Creative Commons licence, unless indicated otherwise in a credit line to the material. If material is not included in the article's Creative Commons licence and your intended use is not permitted by statutory regulation or exceeds the permitted use, you will need to obtain permission directly from the copyright holder. To view a copy of this licence, visit http://creativecommons.org/licenses/by/4.0/.

\section{References}

ACRC (2020) Temperature changes in Alaska. Alaska Climate Research Center. climate.gi.alaska. edu/ClimTrends/Change/TempChange.html. Accessed July 152020

ADLWD (2018) American community survey. State of Alaska. http://live.laborstats.alaska.gov/cen/acsarea.cfm. Accessed November 2018

AMAP (2017) Snow, water, ice and permafrost in the Arctic. Arctic Monitoring and Assessment Programme Oslo, Norway

Ashley S, Ashley W (2008) Flood fatalities in the United States. J Appl Meteorol Climatol 47:805-818

Bieniek P, Bhatt U, Walsh J, Rupp T, Zhang J, Krieger J, Lader R (2016) Dynamical downscaling of ERAinterim temperature and precipitation for Alaska. J Clim Appl Meteorol 55:635-654

Bieniek P, Bhatt U, Walsh J, Lader R, Griffith B, Roach J, Thoman R (2018) Assessment of Alaska rain-on-snow events using dynamical downscaling. Assess Appl Meteorol Climatol 57:1847-1863

Birchall S, Bonnett N (2020) Thinning Sea ice and thawing permafrost: climate change adaptation planning in Nome, Alaska. Environ Hazards 19:152-170

Bouwer L (2011) Have disaster losses increased due to anthropogenic climate change? Bull Am Meteorol Soc 92:39-46

Bouwer L (2013) Projections of future extreme weather losses under changes in climate and exposure. Risk Anal 33:915-930

Bouwer LM (2019) Observed and projected impacts from extreme weather events: implications for loss and damage. In: Mechler R, Bouwer L, Schinko T, Surminski S, Linnerooth-Bayer J (eds) Loss and damage from climate change. Climate risk management, policy and governance. Springer, Cham

Brunner RD, Lynch A, Pardikes J, Cassano E, Lestak L, Vogel J (2004) An arctic disaster and its policy implications. Arctic 57:336-346

C3S (2017) ERA 5: fifth generation of ECMWF atmospheric reanalyses of the global climate. Copernicus Climate Change Service Climate Data Store https://cds.climate.copernicus.eu/cdsapp\#!/home. Accessed 3 Nov 2020

Call D (2010) Changes in ice storm impacts over time: 1886-2000. Weather Clim Soc 2:23-35

Changnon S (2009) Temporal changes in extremely damaging storms. Phys Geogr 30:17-26

City of Nome (2012) Nome comprehensive plan 2020. City of Nome, Nome, Alaska

City of Nome (2017) Alaska hazards mitigation plan update. Nome, Alaska, 101 pages

Dow K (2010) News coverage of drought impacts and vulnerability in the US Carolinas, 1998-2007. Nat Hazards 54:497-518

Downton M, Miller J, Pielke R Jr (2005) Reanalysis of U.S. National Weather Service flood loss database. Nat Hazards Rev 6:13-22

Duerden F (2004) Translating climate change impacts at the community level. Arctic 57:204-212

Earl J, Martin A, McCarthy J, Soule S (2004) The use of newspaper data in the study of collective action. Annu Rev Sociol 30:65-80

Fall J (2016) Subsistence in Alaska: a year 2014 update. Division of Subsistence, Alaska Department of Fish and Game, Anchorage, AK

Fang Z, Freeman P, Field CB, Mach KJ (2018) Reduced Sea ice protection period increases storm exposure in Kivalina, Alaska. Arctic Sci 4:525-537 
Friday E Jr (1994) The modernization and associated restructuring of the National Weather Service: an overview. Bull Am Meteorol Soc 75:43-52

Gall M (2015) The suitability of disaster loss databases to measure loss and damage from climate change. Int J Glob Warming 8:170-190

Haecker D (2012) Nome in a long deep freeze. Nome Nugget, Nome, Alaska

Hallegatte S (2009) Strategies to adapt to an uncertain climate change. Glob Environ Chang 19:240-247

Handmer J et al (2012) Changes in impacts of climate extremes: human systems and ecosystems. In: Field C et al (eds) Managing the risks of extreme events and disasters to advance climate change adaptation. Cambridge University Press, Cambridge, UK, pp 231-290

Huntington $\mathrm{H}$ et al (2020) Evidence suggests potential transformation of the Pacific Arctic ecosystem is underway. Nat Clim Chang. https://doi.org/10.1038/s41558-020-0695-2

Iacono M, Delamere J, Mlawer E, Shephard M, Clough S, Collings W (2008) Radiative forcing by long-lived greenhouse gases: calculations with the AER radiative transfer models. J Geophys Res 113(D13). https://oi. org/10.1029/2008JD009944

IPCC SREX (ed) (2012) Managing the risks of extreme events and disasters to advance climate change adaptation. Cambridge University Press, Cambridge, UK

ISU (2020) Iowa environmental Mesonet. Iowa State University https://mesonet.agron.iastate. edu/request/download.phtml. Accessed 3 Nov 2020

Janjić Z (1994) The step-mountain eta coordinate model: further developments of the convection, viscous sublayer, and turbulence closure schemes. Mon Weather Rev 122:927-945

Kettle N, Martin J, Sloan M (2017) Climate adaptation plan for the Nome-based tribes. Nome Eskimo community; Alaska Center for Climate Assessment and Policy, Fairbanks, AK. https://www.necalaska. org/PDF/6.\%20Tribal_Resources/Nome\%20Tribal\%20Climate\%20Adaptation\%20Plan\%20(FinalLowRes).pdf. Accessed 3 Nov 2020

Knapp C, Trainor S (2015) Alaskan stakeholder-defined research needs in the context of climate change. Polar Geogr 38:42-69

Lader R, Walsh J, Bhatt U, Bieniek P (2017) Projections of 21st century climate extremes for Alaska via dynamical downscaling and quantile mapping. J Appl Meteorol Climatol 56:2393-2409

Lader R, Walsh J, Bhatt U, Bieniek P (2018) Agro-climate projections for a warming Alaska. Earth Interact 22: $1-24$

Larsen J et al (2014) Polar regions. In: Barros V et al (eds) Climate change 2014: impacts, adaptation, and vulnerability. Part B: regional aspects. Cambridge University press, Cambridge, United Kingdom, pp 15671612

Leeper C (1999) DOT drops the bomb: no snow removal in '00. Nome Nugget, Nome, Alaska

Lempert R et al (2018) Reducing risks through adaptation actions. In: Reidmiller D, Avery C, Easterling D, Kunkel K, Lewis K, Maycock T, Stewart B (eds) Impacts, risks, and adaptation in the United States: fourth National Climate Assessment, vol II. U.S. Global Research Program, Washington, DC, pp 1309-1345

Leonard $\mathrm{M}$ et al (2014) A compound event framework for understanding extreme impacts. WIREs Clim Change 5:113-128

Lesk C, Rowhani P, Ramankutty N (2016) Influence of extreme weather disasters on global crop production. Nature 529:84-87

Markon C et al (2018) Alaska. In: Reidmiller D, Avery C, Easterling D, Kunkel K, Lewis K, Maycock T, Stewart B (eds) Impacts, risks, and adaptation in the United States: fourth National Climate Assessment, vol II. U.S. Global Change Research Program, Washington, DC, pp 1185-1241. https://doi.org/10.7930/NCA4.2018. $\mathrm{CH} 26$

Mason O, Salmon D, Ludwig S (1996) The periodicity of storm surges in the Bering Sea from 1989 to 1993 , based on newspaper accounts. Clim Chang 34:109-123

Mastrandrea M, Heller N, Root T, Schneider S (2010) Bridging the gap: linking climate-impacts research with adaptation planning and management. Clim Chang 100:87-101

McAfee S, Guentchev G, Eischeid J (2013) Reconciling projected precipitation trends in Alaska. J Geophys Res 118:7523-7541

Mesquita M, Atkinson DE, Simmonds I, Keay K, Gottschalck J (2009) New perspectives on the synoptic development of the severe October 1992 Nome storm. Geophys Res Lett 36. https://doi.org/10.1029/2009 GL038824

Mitsakis E, Stamos I, Papanikolaou A, Aifadopoulou G, Kontoes H (2014) Assessment of extreme weather events on transport networks: case study of the 2007 wildfires in Peloponnesus. Nat Hazards 72:87-107

Morrison H, Thompson G, Tatarskii V (2009) Impact of cloud microphysics on the development of trailing stratiform precipitation in a simulated squall line: comparison of one-and two-movement schemes. Mon Weather Rev 137:991-1007 
Morss R, Wilhelmi O, Meehl G, Dilling L (2011) Improving societal outcomes of extreme weather in a changing climate: an integrated perspective. Annu Rev Environ Resour 36:1-25

NOAA (2019) NOAA storm event database. National Oceanographic and Atmospheric Administration https:/www.ncdc.noaa.gov/stormevents/. Accessed 18 Nov 2019

NWS (2018) National Weather Service Instruction 10-1605. National Weather Service, Silver Springs, MD

Overeem I, Anderson R, Wobus C, Clow G, Urban F, Matell N (2011) Sea ice loss enhances wave action at the Arctic coast. Geophys Res Lett 38. https://doi.org/10.1029/2011GL048681

Parks M, Ahmasuk A, Compagnoni B, Norris A, Rufe R (2019) Quantifying and mitigating three major vessel waste streams in the northern Bering Sea. Mar Policy 106:103530

Penn H, Gerlach C, Loring P (2016) Seasons of stress: understanding the dynamic nature of people's ability to respond to change and surprise. Weather Clim Soc 8:435-446

Redilla K, Pearl P, Bieniek P, Walsh J (2019) Wind climatology for Alaska: historical and future. Atmos Clim Sci 9:683-702

Rolph R, Mahoney A, Walsh J, Loring P (2018) Impacts of a lengthening open water season on Alaskan coastal communities: deriving locally relevant indices from large-scale datasets and community observations. Cryosphere 12:1779-1790

Skamarock WC, Klemp JB, Dudhia J, Gill DO, Barker D, Duda MG, Powers JG, Wang W, (2008) A description of the advanced research WRF version 3 (No. NCAR/TN-475+STR). University Corporation for Atmospheric Research. https://doi.org/10.5065/D68S4MVH

State of Alaska (2018) State of Alaska Hazard mitigation plan. Anchorage, AK. https://drought.unl. edu/archive/Plans/GeneralHazard/State/AK_2018.pdf. Accessed 3 Nov 2020

Thoman R, Walsh J (2019) Alaska's changing environment: documenting Alaska's physical and biophysical changes through observations. International Arctic Research Center, Fairbanks, AK

Thoman R et al (2020) The record low Bering Sea ice extent in 2018: context, impacts and an assessment of the role of anthropogenic climate change. BAMS:S53-S58

Turner B II et al (2003) A framework for vulnerability analysis in sustainability sciences. Proc Natl Acad Sci 100: 8074-8079

Ungar S (1999) Is strange weather in the air? A study of U.S. national network news coverage of extreme weather events. Clim Chang 41:133-150

USACE (2019) Port of Nome modification feasibility study Nome, Alaska. United States Army Corps of Engineers. https:/www.poa.usace.army.mil/Portals/34/docs/civilworks/publicreview/portofnome/ FinalNomeIFREA29May2020signed.pdf?ver=2020-06-02-192545-533. Accessed 3 Nov 2020

USGCRP (ed) (2018) Impacts, risks, and adaptation in the United States: fourth National Climate Assessment, volume II. U.S. Global Research Program, Washington, DC

Walsh J et al (2018) Downscaling of climate model output for Alaska stakeholders. Environ Model Softw 110: 38-51

Walsh J et al (2020) Extreme climate and weather events in the Arctic. Earth-Sci Rev 209:103324, 1-19

Wang M, Overland J, Stabeno P (2012) Future climate of the Bering and Chukchi seas projected by global climate models. Deep Sea Res Part II 65-70:46-57

Yuan X, Sun X (2019) Climate change impacts on socioeconomic damages from weather-related events in China. Nat Hazards 99:1197-1213

Zhang X, Zhang J (2001) Heat and freshwater budgets and pathways in the Arctic Mediterranean in a coupled ocean/sea-ice model. J Oceanogr 57:207-237

Zhang J, Liu F, Tao W, Krieger J, Shulski M, Zhang X (2016) Mesoscale climatology and variation of surface winds over the Chukchi-Beaufort coastal areas. J Clim 29:2721-2739

Publisher's note Springer Nature remains neutral with regard to jurisdictional claims in published maps and institutional affiliations.

\section{Affiliations}

\section{Nathan P. Kettle $e^{1,2} \cdot$ John E. Walsh ${ }^{1,2} \cdot$ Lindsey Heaney ${ }^{1,2} \cdot$ Richard L. Thoman Jr ${ }^{1,2} \cdot$ Kyle Redilla ${ }^{1} \cdot$ Lynneva Carroll $^{3}$}

1 International Arctic Research Center, University of Alaska Fairbanks, Fairbanks, AK, USA

2 Alaska Center for Climate Assessment and Policy, Fairbanks, AK, USA

3 Honors College, University of Alaska Fairbanks, Fairbanks, AK, USA> 